Jurnal Basicedu Volume 4 Nomor 2 April 2020 Hal. 327-336

JURNAL BASICEDU

Research \& Learning in Elementary Education

https://jbasic.org/index.php/basicedu

\title{
PENGARUH BLANDED LEARNING TERHADAP HASIL BELAJAR MATA KULIAH BIMBINGAN KONSELING MAHASISWA PGSD
}

\author{
Sulistyani Puteri Ramadhani ${ }^{1}$ \\ Universitas Trilogi Jakarta, DKI Jakarta, Indonesia \\ Email: sulistyani@trilogi.ac.id ${ }^{1}$
}

\begin{abstract}
Abstrak
Pada era digitalisasi dalam upaya meningkatkan pembelajaran sebagai kualitas pendidikan di Indonesia selalu merupakan isu yang paling penting. Salah satu cara untuk meningkatkan kualitas pembelajaran di perguruan tinggi adalah dengan meningkatkan kualitas proses mengajar. Proses pembelajaran perlu didukung dengan teknologi untuk memfasilitasi proses pengajaran sehingga dapat belajar di mana saja dan eficienty waktu. Tujuan penelitian ini adalah untuk mengetahui pengaruh penerapan blended learning terhadap hasil belajar mahasiswa Pendidikan Guru Sekolah Dasar pada mata kuliah Bimbingan Konseling. Sampel penelitian adalah Mahasiswa di kelas eksperimen dan Kelas Kontrol. Metode penelitian yang digunakan adalah metode Quasi Eksperimen dengan Postest-Only Control Design. Pengujian hipotesis dilakukan dengan menggunakan uji t. Hasil pengujian hipotesis dengan menggunakan uji t menunjukan bahwa nilai thitung 13,155 dan nilai t tabel dengan $\alpha 0,05$ menunjukan nilai 1,898. Karena thitung $>$ ttabel berarti bahwa terdapat perbedaan hasil belajar mahsisiwa kelas eksperimen yang menerapkan model blended learning dengan hasil belajar siswa kelas kontrol yang tidak menerapkan model blended learning pada mata kuliah bimbingan konseling Dengan adanya perbedaan tersebut dapat disimpulkan bahwa penerapan model blended learning berpengaruh terhadap hasil belajar mahasiswa pada mata kuliah Bimbingan Konseling.
\end{abstract}

Kata Kunci: blended learning, bimbingan konseling, mahasiswa, pendidikan guru sekolah dasar, hasil belajar

\begin{abstract}
In the era of digitalization in an effort to improve learning as the quality of education in Indonesia is always the most important issue. One way to improve the quality of learning in tertiary institutions is to improve the quality of the teaching process. The learning process needs to be supported by technology to facilitate the teaching process so that learning can be anywhere and time efficient. The purpose of this study was to determine the effect of the application of blended learning to student learning outcomes in Primary School Teacher Education in Guidance and Counseling courses. The research sample is students in the experimental class and the control class. The research method used is the Quasi Experiment method with Postest-Only Control Design. Hypothesis testing is done using $t$ test. The results of testing the hypothesis using the $t$ test showed that the $t$ value of 13.155 and the value of $t$ table with $\alpha 0.05$ showed a value of 1.898 . Because tcount $>$ ttable means that there are differences in student learning outcomes of the experimental class applying the blended learning model with the learning outcomes of the control class students who do not apply the blended learning model in the counseling guidance course. With these differences it can be concluded that the application of the blended learning model influences learning outcomes students in the Guidance and Counseling course.
\end{abstract}

Keywords: blended learning, guidance counseling, students, primary school teacher education, learning outcomes

@ Jurnal Basicedu 2020

$\triangle$ Corresponding author :

Address : -

ISSN 2580-3735 (Media Cetak)

Email :-

ISSN 2580-1147 (Media Online)

Phone :- 
328 Pengaruh Blanded Learning terhadap hasl belajar matakuliah bimbingan konseling mahasiswa PGSD - Sulistyani Puteri Ramadhani

\section{PENDAHULUAN}

Diera zaman saat ini perkembangan kemajuan teknologi informasi dan komunikasi saat ini berlangsung begitu pesat, sehingga sudah sewajarnya para pakar menyebut hal ini sebagai suatu perubahan. Sekalipun kemajuan tersebut masih dalam perjalanannya, sejak sekarang sudah dapat diperkirakan bakal terjadi berbagai perubahan di bidang informasi maupun bidangbidang kehidupan lain yang berhubungan, sebagai implikasi dari perkembangan keadaan tersebut. Perubahan-perubahan yang akan dan sedang terjadi, terutama disebabkan oleh potensi dan kemampuan teknologi informasi dan komunikasi yang memungkinkan manusia untuk saling berhubungan (relationship) dan memenuhi kebutuhan mereka akan informasi hampir

tanpa batas. Dahulu manusia sering mengalami kendala kesulitan-kesulitan dikarenakan adanya beberapa keterbatasan dalam berhubungan satu dengan lainnya. Faktor-faktor yang menyebabkan terjadinya kesulitan-kesulitan yang dialamai manusia seperti faktor jarak, waktu, jumlah, kapasitas, kecepatan, dan lain-lain. Saat ini kesulitan-kesulitan manusia dapat diatasi dengan dikembangkannya berbagai Teknologi Informasi dan Komunikasi mutakhir. Misalnya dengan adanya satelit hampir tidak ada lagi batas, jarak, dan waktu untuk menjangkau khalayak yang dituju di mana pun dan kapan pun. Begitu juga dengan kemampuan menerima, mengumpulkan, menyimpan, dan menelusuri kembali informasi yang dimiliki oleh perangkat teknologi informasi seperti komputer, videotape, video compact disc, maka hampir tidak ada lagi hambatan yang dialami untuk memenuhi segala kebutuhan dan keperluan yang berkenaan dengan kemampuan sasaran yang digunakan. Seorang pakar berpendapat bahwa teknologi baru menjanjikan kepada umat manusia akan terbentuknya "jendela dunia", dan teknologi informasi dan komunikasi baru akan membentuk "desa dunia". Dengan demikian teknologi informasi dan komunikasi baru membuat dunia semakin "kecil". Teknologi Informasi dan Komunikasi dalam perkembangannya mempengaruhi dunia pendidikan semakin terasa sejalan dengan adanya pergeseran pola pembelajaran dari tatap muka yang dilakukan secara konvensional ke arah pendidikan yang lebih terbuka dengan memanfaatkan teknologi informasi dan komunikasi sebagai media pembelajaran. Bishop G. (2015) meramalkan bahwa pendidikan masa mendatang akan bersifat luwes (flexible), terbuka, dan dapat diakses oleh siapapun juga yang memerlukannya tanpa memandang faktor jenis kelamin, usia, maupun pengalaman pendidikan sebelumnya. Sedangkan Mason R. (1994) berpendapat bahwa pendidikan mendatang akan lebih ditentukan oleh jaringan informasi yang memungkinkan berinteraksi dan kolaborasi, bukannya gedung sekolah. Pendidikan di Indonesia saat ini dituntut untuk mempersiapkan peserta didik yang cerdas, kreatif serta mandiri. Hal ini sesuai dengan harapan pencapaian keterampilan

abad 21. Pendidikan yang bermutu harus mencakup dua orientasi yakni orientasi akademis yang menitik beratkan pada peserta didik, dan orientasi ketrampilan hidup (Life Skills) untuk memberi bekal kepada peserta didik agar dapat menghadapi kehidupan nyata atau sesungguhnya. Teknologi informasi yang telah menjadi bagian dari pembelajaran di semua jenjang pendidikan di Indonesia, sehingga menuntut sekolah agar memfasilitasi media pembelajarannya.

Dunia pendidikan Indonesia di masa mendatang lebih cenderung berkembang pada bentuk pendidikan terbuka dengan menerapkan 
329 Pengaruh Blanded Learning terhadap hasl belajar matakuliah bimbingan konseling mahasiswa PGSD - Sulistyani Puteri Ramadhani

sistem pendidikan jarak jauh (distance learning). Berbagi sumber belajar bersama antar lembaga penyelenggara pendidikan dalam sebuah jaringan, penggunaan perangkat teknologi informasi interaktif seperti CDROM multimedia, dalam pendidikan secara bertahap menggantikan televisi dan video serta memanfaatkan penggunaan teknologi internet secara optimal dalam pengembangan pembelajaran. Didalam pembelajaran-pembelajaran yang akan dikembangkan akan menggabungkan pembelajaran konvensional dengan pembelajaran berbasis teknologi informasi dan komunikasi (TIK). Pembelajaran-pembelajaran yang menggabungkan antara pembelajaran konvensional dengan pembelajaran berbasis teknologi informasi dan komunikasi itulah yang dikembangkan sebagai pembelajaran campuran atau lebih dikenal dengan istilah Blended Learning, yaitu menggabungkan pembelajaran konvensional (hanya tatap muka) dengan pembelajaran dengan memanfaatkan teknologi informasi dan komunikasi. Melalui Blended Learning sistem pembelajaran menjadi lebih luwes dan tidak kaku.

Pengertian Blended Learning Istilah Blended Learning secara ketatabahasaan terdiri dari dua kata yaitu Blended dan Learning. Kata Blend berarti "campuran bersama untuk meningkatkan kualitas agar bertambah baik" (Elmeida \& Pranajaya, 2017). Ditambahkan menurut Elenena Mosa (2006) menyampaikan bahwa yang dicampurkan adalah dua unsur utama, yakni pembelajaran di kelas dengan tatap muka secara konvensional (classroom lesson) dengan pembelajaran secara online. Ini yang dimaksudkan adalah pembelajaran yang secara konvensional biasa dilakukan di dalam ruangan kelas dikombinasikan dengan pembelajaran yang dilakukan secara online baik yang dilaksanakan secara independen maupun secara kolaborasi, dengan menggunakan sarana prasarana teknologi informasi dan komunikasi.

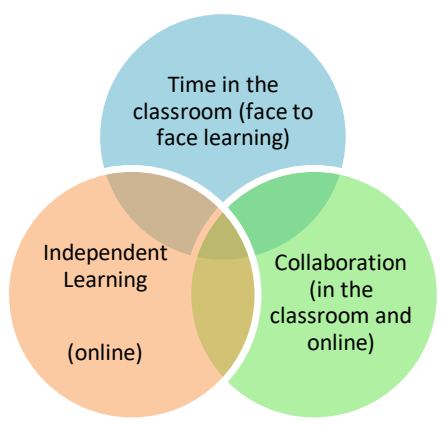

Gambar 1. Konsep Blended Learning (Sumber http://orangecharterschool.org/the-future-of-

learning-has-arrived-at-ocs/)

Selain Blended Learning ada istilah lain yang sering digunakan di antaranya Blended eLearning dan hybrid learning. Istilah yang disebutkan tadi mengandung arti yang sama yaitu perpaduan, percampuran atau kombinasi pembelajaran. Untuk lebih mudah memahami perbedaan istilah-istilah tersebut, Mainnen (2008) yang menyebutkan "Blended learning mempunyai beberapa alternatif nama yaitu mixed learning, hybrid learning, Blended e-learning dan melted learning (bahasa Finlandia)." Karena model pembelajaran campuran ini lebih banyak menggunakan blended e-learning pada pembelajaran dari pada tatap muka atau residensial dan tutorial kunjung, maka penulis menggunakan istilah Blended e-learning. Selain itu Heinze (2008;1 4) juga berpendapat “A better term for 'Blended Learning' is 'blended Blended elearning'.,

Jadi Blended Learning dapat diartikan sebagai proses pembelajaran yang memanfaatkan berbagai macam pendekatan. Pendekatan yang dilakukan dapat memanfaatkan berbagai macam media dan teknologi. Secara sederhana dapat dikatakan bahwa Blended Learning adalah pembelajaran yang mengkombinasikan antara tatap muka (pembelajaran secara konvensional, dimana antara 
330 Pengaruh Blanded Learning terhadap hasl belajar matakuliah bimbingan konseling mahasiswa PGSD - Sulistyani Puteri Ramadhani

peserta didik dan pendidik saling berinteraksi secara langsung, masing-masing dapat bertukar informasi mengenai bahan-bahan pegajaran), belajar mandiri (belajar dengan berbagai modul yang telah disediakan) serta belajar mandiri secara online. Penerapan Blended Learning tidak terjadi begitu saja. Beberapa hal yang menjadi pertimbangan yaitu karakteristik tujuan pembelajaran yang ingin kita capai, aktifitas pembelajaran yang relevan serta memilih dan menentukan aktifitas mana yang relevan dengan konvensional dan aktifitas mana yang relevan untuk online learning.

Tujuan Blended Learning . 1)Membantu pendidik untuk berkembang lebih baik didalam proses belajar, sesuai dengan gaya belajar dan preferensi dalam belajar. 2) Menyediakan peluang yang praktis realistis bagi guru dan pendidik untuk pembelajaran secara mandiri, bermanfaat, dan terus berkembang 3) Peningkatan penjadwalan fleksibilitas bagi pendidik, dengan menggabungkan aspek terbaik dari tatap muka dan instruksi online. Kelas tatap muka dapat digunakan untuk melibatkan para siswa dalam pengalaman interaktif. Sedangkan kelas online memberikan pendidik, sedangkan porsi online memberikan para siswa dengan konten multimedia yang kaya akan pengetahuan pada setiap saat, dan di mana saja selama pendidik memiliki akses internet.

\section{Kelebihan dan Kekurangan Blended}

Learning Kelebihan Blended Learning : • Pembelajaran terjadi secara mandiri dan konvensional, yang keduanya memiliki kelebihan yang dapat saling melengkapi. - Pembelajaran lebih efektif dan efisien - Meningkatkan aksesbiltas. Dengan adanya Blended Learning maka peserta belajar semakin mudah dalam mengakses materi pembelajaran.

Kekurangan Blended Learning : 1) Media yang dibutuhkan sangat beragam, sehingga sulit diterapkan apabila sarana dan prasarana tidak mendukung. 2) Tidak meratanya fasilitas yang dimiliki pelajar, seperti komputer dan akses internet. Padahal dalam Blended Learning diperlukan akses internet yang memadai, apabila jaringan kurang memadai akan menyulitkan peserta dalam mengikuti pembelajaran mandiri via online. 3) Kurangnya pengetahuan masyarakat terhadap penggunaan teknologi 4)Tidak meratanya fasilitas yang dimiliki pelajar, seperti komputer dan akses internet.

Pada pelaksanaan proses pembelajaran Bimbingan Konseling dengan menerapkan Blended Learning maupun secara konvensional, pendidik perlu mengembangkan langkah-langkah pembelajaran yang tepat dalam suatu Rencana Pelaksanaan Semester (RPS) Bimbingan Konseling berdasarkan kompetensi dasar yang ingin dicapai dalam pembelajaran.

Pengembangan

langkah-langkah pembelajaran yang menerapkan Blended Learning juga perlu dirancang dengan baik, sehingga dalam pelaksanaan pembelajarannya peserta didik tidak merasa kesulitan secara teknis. Oleh karena itu, pendidik perlu mempersiapkan terlebih dulu segala hal yg dibutuhkan, seperti materi-materi yang akan disampaikan atau dibahas, platform yang akan digunakan dalam pembelajaran dengan Blended Learning, tutorial penggunaan platform yang digunakan dalam pembelajaran dengan menerapkan Blended Learning dan lain sebagainya.

Sebelum melaksanakan proses pembelajaran dengan menerapkan Blended Learning, pendidik harus menyiapkan dulu semua kebutuhan pembelajarannya terutama penggunaan platform teknologi yang akan digunakan dalam pembelajaran yang akan digunakan tanpa melaksanakan tatap muka. Beberapa platform yang dapat digunakan dalam pembelajaran dengan 
331 Pengaruh Blanded Learning terhadap hasl belajar matakuliah bimbingan konseling mahasiswa PGSD - Sulistyani Puteri Ramadhani

Blended Learning seperti tugas online, materi pembelajaran dan sebagainya. Selanjutnya, bagaimana platform-platform yang sudah ditentukan oleh pendidik diterapkan dalam pembelajaran dengan sebelumnya disusun terlebih dahulu dalam langkah-langkah pembelajaran yang dirancang.

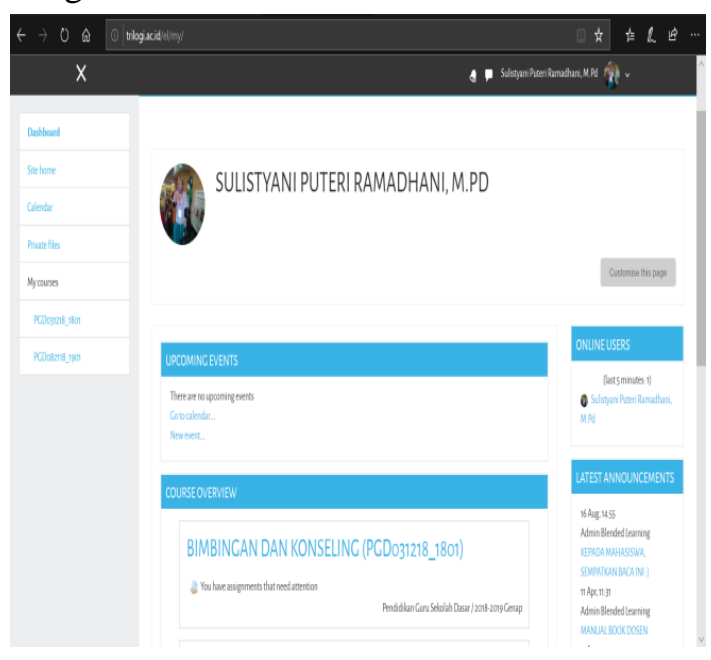

Gambar 2 layout blanded

(Sumber : www.trilogi.com/el)

Berikut contoh Website Berbasis Moodle untuk menerapkan blanded learning yang dipakai Universitas Trilogi. Dihalaman home terdapat mata kuliah yang akan diberikan blanded learning.

Langkah selanjutnya yaitu merancang pertemuan yang akan di blanded dibagian home mata kuliah.

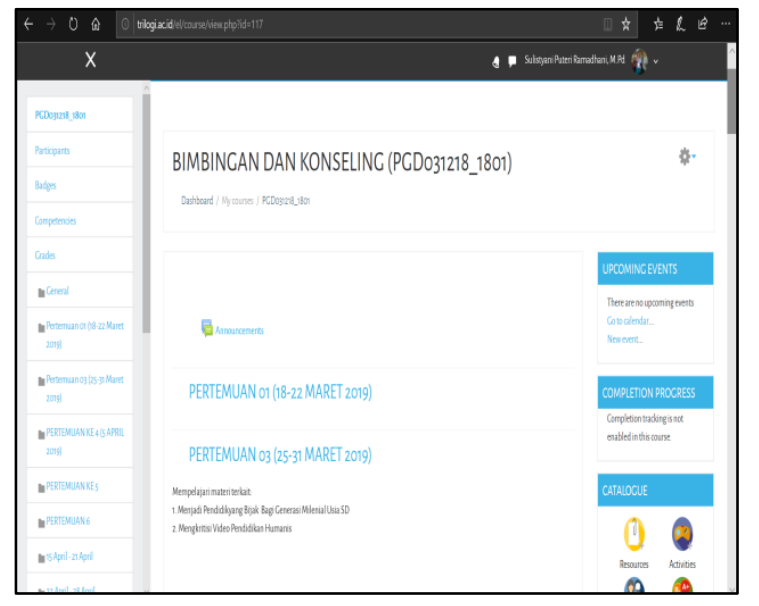

Gambar 3 layout tugas
Setelah membuat rancangan, kemudian menyusun tugas, forum dan quiz. Display dapat dilihat seperti berikut ini :

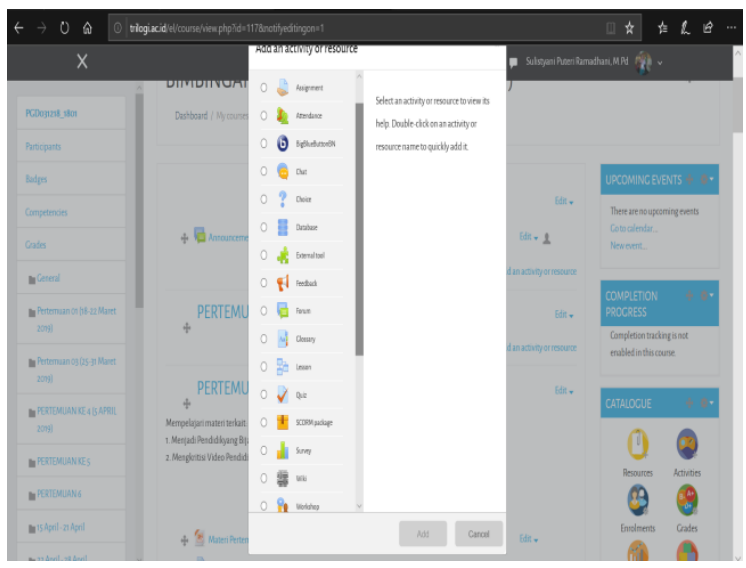

Gambar 4 layout forum

Sistem proses pembelajaran Blended Learning merupakan proses pembelajaran yang memanfaatkan berbagai macam pendekatan. Pendekatan yang dilakukan dapat memanfaatkan berbagai macam media dan teknologi. Pembelajaran berlangsung secara konvensional (tatap muka), mandiri, dan mandiri via online. Bahan belajar mandiri secara offline disiapkan dalam bentuk digital, seperti dalam bentuk digital online dll, sedangkan bahan belajar mandiri secara online disiapkan dalam bentuk Social Media, atau menu yang telah tersedia dan lain sebagainya. Pelaksanaan pembelajaran dengan Blended Learning secara online dapat diterapkan dalam beberapa model yaitu web course, web centric course, dan web enhanced course. Pada implemenatasinya, pembelajaran dengan blended learning pada lembaga pendidikan dasar dan menengah lebih tepat dengan menerapkan model web centric course, dan web enhanced course, karena blanded learning diwajibkan adanya tatap muka di dalam kelas.

Pada penerapan Blended Learning pendidik seharusnya dapat memastikan bahwa seluruh pesertanya memiliki sarana dan prasarana yang 
332 Pengaruh Blanded Learning terhadap hasl belajar matakuliah bimbingan konseling mahasiswa PGSD - Sulistyani Puteri Ramadhani

memadai, sehingga dalam belajar secara mandiri via online tidak banyak hambatan dikarenakan faktor sarana dan prasana yang kurang memadai. Selain itu pendidik sudah menyiapkan solusi terbaik dalam mengatasi permasalahan yang mungkin muncul. Pembagian materi belajar harus dapat dialokasikan dengan baik, dengan mempertimbangkan isi bahan ajar, serta tujuan pembelajarannya, mana yang harus dibahas secara tatap muka, atau dapat dipelajari secara mandiri. Dalam mengorganisir pembelajaran, pendidik juga harus menyiapkan jadwal yang terorganisir untuk tatap muka dan pembelajaran mandiri diawal, agar peserta mengetahui secara jelas jadwal tersebut.

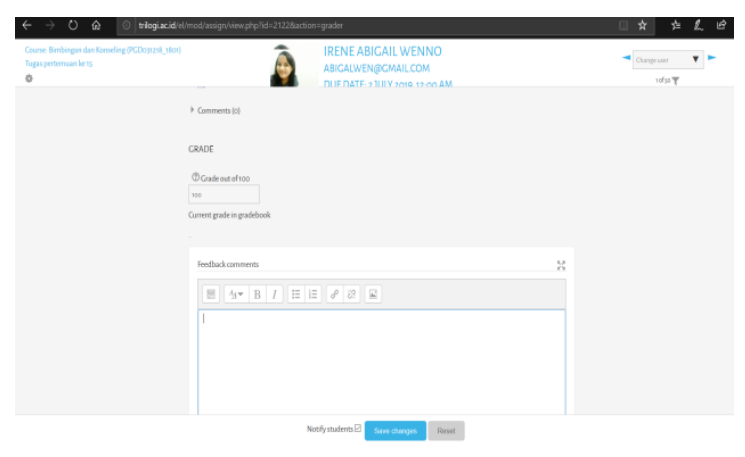

Gambar 6 layout penilaian

Setelah mahasiswa mengerjakan tugas, dosen dapat menginput nilai yang akan diberikan kepada mahasiswa, dan mahasiswa dapat melihat feedback yang diberikan dosen.

\section{METODE}

Metode Penelitian yang digunakan dalam penelitian ini adalah metode eksperimen. Metode eksperimen ditujukan untuk meneliti hubungan sebab-akibat dengan memanipulasikan satu atau lebih variabel pada satu (atau lebih) kelompok eksperimental dengan membandingkan hasilnya dengan kelompok control yang tidak mengalami manipulasi. Manipulasi berarti merubah secara sistematis sifat-sifat (nilai-nilai) variabel bebas.Setelah dimanipulasikan, variabel bebas itu biasanya disebut treatment.Desain yang digunakan adalah desain Quasy Eksperimen dengan menggunakan Postest-Only Control Design. Desain ini dapat dituangkan kedalam skema sebagai berikut:

\section{$\mathrm{E} \mathrm{X} \mathrm{O2}$ \\ $\mathrm{K}-\mathrm{O} 4$}

Gambar 6 Desain Penelitian (Sugiyono 2012 : 85)

Desain ini dilakukan dengan satu macam perlakuan, yakni penerapan model blended learning. Pada kelas eksperimen diberikan perlakuan (X) yaitu model blended learning dan pada kelas kontrol tidak diberikan perlakuan (-).

Kemudian setelah selesai perlakuan, kedua kelas diberikan posstest untuk mengetahui kondisi kelas setelah diberikan perlakuan. Setelah itu menguji perbedaan antara hasil posstest pada masing masing kelas.

\section{HASIL DAN PEMBAHASAN}

Hasil dan Pembahasan Pada penelitian ini, model blended learning diterapkan pada kelas eksperimen yaitu Mahasiswa Kelas Karyawan setelah pertemuan pembelajaran semesteran. Setelah model blended learning diterapkan, maka dilakukan postes untuk mengukur hasil belajar siswa. Dan untuk melihat apakah model blended learing membantu siswa dalam meningkatkan hasil belajarnya, maka pendidik membandingkan hasil belajar kelas eksperimen tersebut dengan hasil belajar kelas kontrol atau kelas yang tidak menerapkan model blended learning.

Langkah awal adalah uji homogenitas untuk melihat apakah kedua kelas memiliki data yang homogen agar bisa dibandingkan atau sebaliknya memiliki data yang heterogen sehingga tidak bisa dibandingkan. Dan setelah dilakukan uji varians, didapatkan bahwa Fhitung 1,1035 < Ftabel 1,1814 dan kedua kelas dinyatakan 
333 Pengaruh Blanded Learning terhadap hasl belajar matakuliah bimbingan konseling mahasiswa PGSD - Sulistyani Puteri Ramadhani

homogen, maka guru memberikan soal postes yang sama untuk membandingkan apakah terdapat perbedaan hasil belajar pada kelas eksperimen dengan hasil pembelajaran pada kelas kontrol. Sebelum dilakukan uji hipotesis, peneliti melakukan uji normalitas dari data hasil postes kelas kontrol dan eksperimen, dan didapatkan bahwa keduanya memiliki data yang berdistribusi normal sehingga data dapat dilihat terdapat perbedaan atau tidak melalui uji statistika parametrik.

Setelah dilakukan pengujian data menggunakan uji t, didapatkan bahwa thitung 11,455 > nilai ttabel 1,998 sehingga $H 0$ ditolak dan $H 1$ diterima. Dengan demikian berarti bahwa terdapat perbedaan hasil belajar siswa kelas eksperimen yang menerapkan model pembelajaran blended learning dengan hasil belajar siswa kelas kontrol yang tidak menerapkan model pembelajaran blended learning. Berdasarkan pengolahan data, rata-rata nilai postest kelas eksperimen adalah 92,72. Sedangkan, pada kelas kontrol rata-rata nilai postest nya adalah 77,27. Artinya, terdapat perbedaan ratarata yang signifikan antara kelas eksperimen dan kelas kontrol. Jumlah siswa yang sudah mencapai KKM pada kelas eksperimen adalah sebanyak 31 orang siswa sehingga persentase ketuntasannya adalah sebesar 96,87\%. Sedangkan jumlah siswa yang sudah mencapai KKM pada kelas kontrol adalah sebanyak 26 siswa sehingga persentase ketuntasannya sebesar 78,79\%. Adanya perbedaan hasil belajar pada kedua kelas tersebut menunjukkan bahwa model blended learning yang diterapkan pada kelas eksperimen berpengaruh positif terhadap hasil belajar siswa pada mata pelajaran akuntansi, khususnya pada materi mengelola jurnal khusus pada perusahaan dagang. Berikut ini adalah perolehan nilai siswa kelas eksperimen dan kelas kontrol : Dilihat dari hasil belajar siswa kelas kontrol dan kelas eksperimen berbeda, hal ini terlihat dari perbedaan nilai ratarata dari kedua kelas tersebut dan kelas eksperimen lebih unggul dibandingkan dengan kelas kontrol. Hal ini disebabkan karena terdapat perbedaan model pembelajaran yang diterapkan kepada kedua kelas tersebut. Pada kelas kontrol yang tidak menerapkan model blended learning guru memberikan penjelasan materi hanya pada saat jam pembelajaran dikelas saja. Guru memberikan materi pembelajaran dengan menggunakan metode ceramah.

Pembelajaran berlangsung satu arah. Sehingga menyebabkan beberapa siswa masih belum memahami materi tersebut. Materi mengenai jurnal khusus merupakan materi inti bimbingan konseling. Dengan penerapan model blended learning siswa memiliki waktu yang lebih banyak untuk berinteraksi dengan pendidik. Sehingga mahasiswa yang masih belum memahami materi pembelajaran dikelas dapat berkonsultasi lebih lanjut dengan pendidik. Dalam pembelajaran dikelas, pendidik dapat menjelaskan materi kepada mahasiswa dengan berbagai metode pembelajaran dan siswa dapat menanyakan secara langsung materi pembelajaran yang belum dipahaminya.

Dalam pembelajaran online siswa diberikan materi tambahan melalui ebook yang dibagikan melalui media sosial, video pembelajaran, serta artikel yang direkomendasikan pendidik/dosen untuk dipelajari oleh siswa. Pada saat pembelajaran dikelaspun siswa diberikan penjelasan kembali mengenai materi yang belum tuntas dibahas pada pembelajaran online. Sehingga pemahaman siswa dapat diperkuat dengan adanya penjelasan materi dan soal-soal latihan yang diberikan oleh pendidik atau guru.

Perbedaan model pembelajaran yang berbeda pada kelas yang berbeda memiliki 
334 Pengaruh Blanded Learning terhadap hasl belajar matakuliah bimbingan konseling mahasiswa PGSD - Sulistyani Puteri Ramadhani

pengaruh terhadap hasil belajar siswa. Dapat dilihat bahwa kelas yang menerapkan model blended learning memiliki hasil belajar yang cukup tinggi dibandingkan dengan kelas yang menerapkan pembelajaran face to face saja. Hal ini sejalan dengan pengungkapan Aunurrahman (2013 : 143) yang menegaskan bahwa penggunaan model pembelajaran yang tepat dapat mendorong tumbuhnya rasa senang siswa terhadap pelajaran, menumbuhkan dan meningkatkan motivasi dalam mengerjakan tugas, memberikan kemudahan bagi siswa untuk memahami pelajaran sehingga memungkinkansiswa mencapai hasil belajar yang lebih baik. Dengan demikian dapat dikatakan bahwa penerapan model blended learning memiliki pengaruh yang positif terhadap hasil belajar siswa. Sehingga model ini efektif jika diterapkan pada mata pelajaran bimbingan konseling. Tetapi peneliti tidak bisa membuat kesimpulan bahwa model blended learning ini efektif untuk semua kompetensi inti dalam mata pelajaran. Penerapan model ini harus melihat karakteristik materi yang akan disampaikan, apakah materi tersebut memerlukan intensitas latihan yang sering atau hanya sekedar pemahaman teori dan konsep saja.

Hal ini sesuai dengan pengungkapan Faizal (dalam Husamah, 2014 : 34) bahwa 'Implementasi blended learning dapat mengingkatkan hasil belajar peserta didik'. Penelitian yang dilakukan sebelumnya juga mengatakan bahwa model blended learning dapat meningkatkan hasil belajar siswa. Penelitian yang dilakukan Syarif Izuddin tahun 2012 yang berjudul "Pengaruh Penerapan Model Blended Learning Terhadap Motivasi Dan Prestasi Belajar Siswa SMKN 1 Paringin" menunjukan bahwa terdapat perbedaan yang signifikan antara prestasi belajar siswa yang menggunakan model blended learning dan siswa yang menggunakan model face-to-face learning serta terdapat peningkatan prestasi belajar yang signifikan akibat adanya penerapan model blended learning. Begitupula dengan penelitian yang dilakukan oleh Akkoyunlu, B., \& Soylu, MY tahun 2008 yang berjudul “A Study of Student's Perceptions in a Blended Learning Environment Based on Different Learning Styles" menunjukkan bahwa hasil belajar siswa dapat meningkat dengan tidak menghilangkan proses tatap muka dikelas. Dari hasil pengamatan yang dilakukan selama eksperimen, menunjukkan bahwa pelaksanaan model blended learning sejalan dengan pendapat Kusni (dalam Husamah, 2014 : 37) yang mengungkapkan bahwa : 1. Pengajar perlu memiliki keterampilan dalam menyelenggarakan e-learning 2. Pengajar perlu menyiapkan referensi digital yang dapat menjadi acuan bagi peserta didik 3. Pengajar perlu merancang referensi yang sesuai atau terintegrasi dengan tatap muka 4. Pengajar perlu menyiapkan waktu untuk mengelola pembelajaran berbasis internet, misalnya untuk mengembangkan materi, mengembangkan instrumen asesmen dan menjawab berbagai pertanyaan yang diajukan mahasiswa.

Dari hasil pengamatan, model blended learning dapat diterapkan dengan memperhatikan hal-hal berikut: 1. Pemahaman dan kesiapan guru dalam melaksanakan tahap demi tahap sesuai dengan aturan pada penerapan model blended learning 2. Pemahaman dan kesiapan mahasiswa untuk melaksanakan kegiatan pembelajaran. Pemahaman dan kesiapan terhadap setiap tahap tahap kegiatan pembelajaran dengan model blended learning sangat penting agar kegiatan pembelajaran berlangsung dengan lancar dan tujuan pembelajaran dapat tercapai 3. Tersedianya waktu yang cukup untuk melaksanakan langkahlangkah model blended learning. Terutama dalam penjadwalan pembelajaran online yang harus disesuaikan dengan kemampuan siswa dan juga 
335 Pengaruh Blanded Learning terhadap hasl belajar matakuliah bimbingan konseling mahasiswa PGSD - Sulistyani Puteri Ramadhani

dosen 4. Ketersediaan fasilitas dan bahan ajar yang dibutuhkan pada saat menerapkan model blended learning. Contohnya: tersedianya fasilitas internet yang memadai sehingga semua siswa dapat mengakses sumber belajar online. Sehingga dengan terpenuhinya hal-hal di atas, pelaksanaan model blended learning dapat berjalan secara efektif dan

membantu siswa dalam mencapai tujuan pembelajaran dan hasil pembelajaran yang optimal.

\section{SIMPULAN}

Kesimpulan Berdasarkan hasil penelitian yang telah dilakukan di Program Studi Universitas Trilogi Jakarta, maka dapat disimpulkan bahwa:

1. Penerapan model blended learning berlangsung efektif pada kelas eksperimen yaitu mahasiswa prodi PGSD. Pada pertemuan pertama siswa mengikuti pembelajaran dikelas, mengirim tugas menggunakan email, ataupun forum dan diperkenalkan dengan media sosial. Pada pertemuan kedua guru memberikan sumber belajar tambahan seperti ebook, file, artikel dan video pembelajaran kepada siswa untuk menunjang proses pembelajaran. pada pertemuan ketiga guru memberikan review materi yang telah disampaikan dan siswa mengerjakan latihanlatihan soal. Dalam pelaksanaan blended learning tidak terlepas dari berbagai hambatan diantara lain adalah masih kurangnya sosialisasi kepada siswa tentang penggunaan media sosial, kurangnya waktu pembelajaran dan keterbatasan siswa untuk mengakses internet. Namun secara keseluruhan pelaksanaan blended learning telah berlangsung dengan cukup baik. Hal ini ditunjukan dengan hasil penyebaran angket observasi, 50\% siswa mengatakan bahwa efektivitas penerapan model blended learning secara umum berada pada kategori sedang. Efektivitas penerapan forum, Assesment berada pada kategori sedang

2. Terdapat perbedaan hasil belajar mahasiswa bimbingan konseling yang menerapkan model pembelajaran blended learning dengan hasil belajar siswa kelas konvensional yang tidak menerapkan model blended learning

\section{DAFTAR PUSTAKA}

Akkoyunlu, B., \& Soylu, M. Y. (2008). A Study of Student's Perceptions in a Blended Learning Environment Based on DifferentLearning Styles.

Arifin, Z. (2011). Penelitian Pendidikan : Metode \& Paradigma Baru. Bandung : PT.Remaja Rosdakarya

Arikunto, S. (2011). Dasar-Dasar Evaluasi Pembelajaran.Jakarta : Bumi Aksara

Aunurrahman. (2013). Belajar dan Pembelajaran.Bandung : Alfabeta

Budiningsih, A. (2005). Belajar dan Pembelajaran. Jakarta : Rineka Cipta

Cipta Djamarah, SB (2000). Psikologi Belajar. Jakarta : Rineka Cipta

Dimyati dan Mudjiono. (2009). Belajar dan Pembelajaran. Jakarta : Rineka

Elmeida, I. F., \& Pranajaya, R. (2017). Pengaruh

Metode Pembelajaran Blended Learning

Terhadap Motivasi Belajar Mahasiswa

Kebidanan Poltekkes Tanjungkarang. Jurnal

Keperawatan, XIII(1), 35-41. Retrieved from http://ejurnal.poltekkes-

tjk.ac.id/index.php/JKEP/article/view/848

Firdaus (eds). (2008). Pembelajaran Terkini

Perpaduan Indonesia-Malaysia.Yogyakarta :

Pustaka

Husamah. (2014). Pembelajaran Bauran (Blended Learning). Jakarta : Prestasi Pustakarya Isjoni dan L.N 
336 Pengaruh Blanded Learning terhadap hasl belajar matakuliah bimbingan konseling mahasiswa PGSD - Sulistyani Puteri Ramadhani

Jurnal : M. Yusuf. T. (2011).Blended Learning : Model Pembelajaran KombinasiE-Learning Dalam Pendidikan Jarak Jauh. Vol. 14 No 2 p.232.242 Yusuf. (2011). Mengenal Blended Learning. Lentera Pendidikan, VOL. 14 No. 2

Prosedur Penelitian Suatu Pendekatan Praktik. Jakarta. : Rineka cipta

Riyanto, Y. (2010). Paradigma Baru Pembelajaran:

Sebagai Referensi Bagi Guru/ Pendidik

Dalam Implementasi Pembelajaran yang

Efektif dan Berkualitas. Jakarta : Kencana Prenada Media Grup

Sagala, S. (2010). Konsep dan Makna Pembelajaran. Bandung : Alfabeta Slameto.(2010). Belajar Dan FaktorFaktor Yang Mempengaruhinya. Jakarta : PT. Rineka Cipta.

Sugiyono. (2005).Memahami Penelitian Kualitatif. Bandung: Alfabeta

Sukardi. (2010). Evaluasi Pendidikan : Prinsip dan Operasionalnya. Jakarta : Bumi Aksara

Suprayekti. (2003). Interaksi Belajar Mengajar. Jakarta : Direktorat Tenaga Kependidikan, Dikdasmen, Depdiknas. Depdiknas.

Syah, M. (2011). Psikologi Pendidikan Suatu Pendekatan Baru. Bandung: Remaja Rosdakarya. (2006). Psikologi Belajar. Jakarta: Raja Grafindo Persada Uno, H.B dan Lamatenggo.N. (2010). Teknologi Komunikasi dan Informasi Pembelajaran. Jakarta : Bumi Aksara

Tarsito (2010). Evaluasi Proses Dan Hasil

Pembelajaran.Jakarta : Bumi Aksara 